\title{
Economic Learning Media Development Based on Local Locality
}

\author{
Rizali Hadi ${ }^{1}$, Supriyanto ${ }^{1} \&$ Mahmudah Hasanah $^{1}$ \\ ${ }^{1}$ Universitas Lambung Mangkurat Banjarmasin \\ Correspondence: Priyono, Post Graduate Management Program, Universitas Bina Darma Palembang, Indonesia.
}

Received: May 2, 2017

Accepted: June 19, 2017

Online Published: June 22, 2017

doi:10.5430/ijhe.v6n3p188

URL: https://doi.org/10.5430/ijhe.v6n3p188

\begin{abstract}
This study aims to describe the learning medium of economic education at senior High School in Banjarmasin with media based on local wisdom.

This research uses qualitative method as developed by Miles \& Huberman, starting from data collection, data reduction data display, and then made conclusion. Data were collected in the order of Basic Competence (KD) of Economics lesson, from Class X, XI, and XII. The data are grouped into media that are (a) audio, (b) visual, and (c) audio \& visual. Respondents are economic teachers, MGMP Economics, the school, especially the principal in question.

From this research, it is known that the use of learning media based on local wisdom in high school in Banjarmasin City has been done mostly using audio, visual or audio \& visual media, in every Basic Competence (KD) of economic learning. Already there are inserted with the media based on local wisdom, but has not been explored to the fullest.
\end{abstract}

Keywords: Economic Learning, Learning Media, Local Wisdom

\section{Introduction}

Teaching and learning process requires media, because according to Kemp and Dayton (1985) media has benefits (a) the delivery of materials can be uniformed, (b) the learning process becomes interesting, (c) the learning process is more interactive, (d) the amount of teaching and learning time can be reduced, (e) the quality of learning can be improved, (f) the learning process can occur anywhere and anytime, and (g) the teacher's role can change in a positive and productive direction. In the economic learning in high school has many that have been prepared by the Department of Education nationally, but if the subject of economic learning related to local content seems not yet unearthed. According to Bretz (1971), the media is divided into three types: (a) audio, audible media, (b) visual media ie visible media, and (c) media that can be heard and seen or moved. Media based on local wisdom can also be delivered through these three kinds of media.

Problems relating to economic learning media, often forgetting traditional trading practices, in terms of trade size and behavior. Traditional Market as the implementation of space utilization which is a space for the community (seller - buyer) interact directly in the process of buying and selling. Traditional market as one form of spatial arrangement in the city in the utilization of urban space that supports economic activity locally. Traditional market as a place of mobility, interaction of people directly in transactions. In the traditional market communication occurs directly between the seller and the buyer because there is a bargaining process in which the seller sets the agreed price by raising slightly from the standard price.

This research indicates that the teacher does not bother with the problem of this learning media, because there is no obligation to make it, and also no one is watching it. Teachers are already comfortable with what is available in textbooks, as well as media provided by the school. There is a possibility that teachers are reluctant to use the existing media because it is no longer feasible or the number is less and can be used at the same time with other teachers. Available media, especially national ones, rarely come into contact with local wisdom. Now it is time to develop the local wisdom learning media, to introduce to the present generation to compare it with the national media. Various activities, designations, measuring tools and naming of transactions locally have begun to be forgotten because of the rapid progress of economic activity today.

Studies have shown that the application of learning guided by variation theory enhances the learning ability and the ability of teachers and students. However, these encouraging results are evident in studies conducted in Hong Kong 
SAR and China Mainland (Lai, 2005; Lo, Pong, and Chik, 2005; Pang, 2002; Pang, 2006; Ma, 1999; Marton and Tsui, 2004; Keung, 2009), Sweden (Runesson, 2005), and English (Thabit, 2006). Carry out study lessons in developing countries, installing new study areas with different stops in cultures and contexts with western and eastern countries. Inspired by positive teacher learning outcomes, the need to adapt the model as a platform to engage teachers in reflecting on the best way to implement the development of local wisdom-based economic learning media in senior High School in Banjarmasin city.

Media with local wisdom is a media that shows regional characteristics, with the aim of introducing to students the local wisdom of the region.

\section{Research Methods}

The design used in this research is qualitative research as developed by Miles \& Huberman (1992), starting from data collection, data reduction data display, and then made conclusion. To collect data, interviews were conducted in the following order of Basic Competence of Economics lessons, from Class X, XI, and XII. Data obtained on learning media that are audio, visual, and audio \& visual. This study aims to enrich the learning media of economic education at senior High School in Banjarmasin City with media based on local wisdom.

This research is descriptive, that is describe what is and what is done by teacher of economic subject in conducting its teaching and learning process. This research is also a qualitative research, generally do not specify the number of samples first. However, for this study, it is determined purposively about which school is chosen and taken approximately $60 \%$ both Senior High School and Senior High School Private. This study also considered the distribution of schools within the city of Banjarmasin. Each teacher of the selected sample will be interviewed about what medium he uses in each Basic Competency in classes X, XI, and XII, and what medium he has ever made for a media based on local wisdom. In addition interviewed also the school associated with this learning media. As the validation is also conducted interviews to the deliberations of teachers of economic subjects Banjarmasin about instructional media in question.

Table 1. Senior High School in Banjarmasin City

\begin{tabular}{llllll}
\hline Number & School & State & Private & Amount & Sample (60\%) \\
\hline 1 & Senior High School & 13 & 7 & 20 & 13 \\
2 & Vocational High School & 5 & 12 & 17 & 10 \\
3 & Islamic Senior High School & 3 & 4 & 7 & 2 \\
Total Amount & $\mathbf{2 1}$ & $\mathbf{2 3}$ & $\mathbf{4 4}$ & $\mathbf{2 5}$ \\
\hline
\end{tabular}

Source: Education Department of Banjarmasin City (2016)

The data collected (data collection) will be reduced (data reduction) or directly presented (data display) to conclusion (conclusion, drawing/verification), in accordance with qualitative data analysis Model Miles \& Huberman (Rohidi, 1992). The collected data, which has been reduced and has been displayed, will be used as material for further analysis after verification is taken as a result of the research. The results of this study serve as a reference for developing a media based on local wisdom. In the next stage will be conducted trials, validation and verification until the socialization of media-based local wisdom to teachers who care for economic lessons.

\section{Research Result}

\section{Recapitulation of Use of Learning Media}

\begin{tabular}{lllllll}
\hline \multirow{2}{*}{ Class } & No & Basic Competencies & \multicolumn{2}{c}{ Type of Media Used } & & Number \\
\cline { 3 - 6 } & & Audio & Visual & $\begin{array}{c}\text { Audio } \\
\text { Visual }\end{array}$ & \& School \\
\hline $\mathrm{X}$ & 3.1 & Understand the basic concepts of economics & 10 & 6 & 9 & 25 \\
\cline { 2 - 6 } & 3.2 & $\begin{array}{l}\text { Analyze scarcity (the relationship between } \\
\text { resources and human needs) and strategies to } \\
\text { address resource scarcity }\end{array}$ & 6 & 11 & 8 & 25 \\
\hline & $\begin{array}{l}\text { Analyze the main economic issues (what, } \\
\text { how, and for whom) and alternative solutions } \\
\text { through various economic systems }\end{array}$ & 6 & 13 & 25 \\
\hline
\end{tabular}




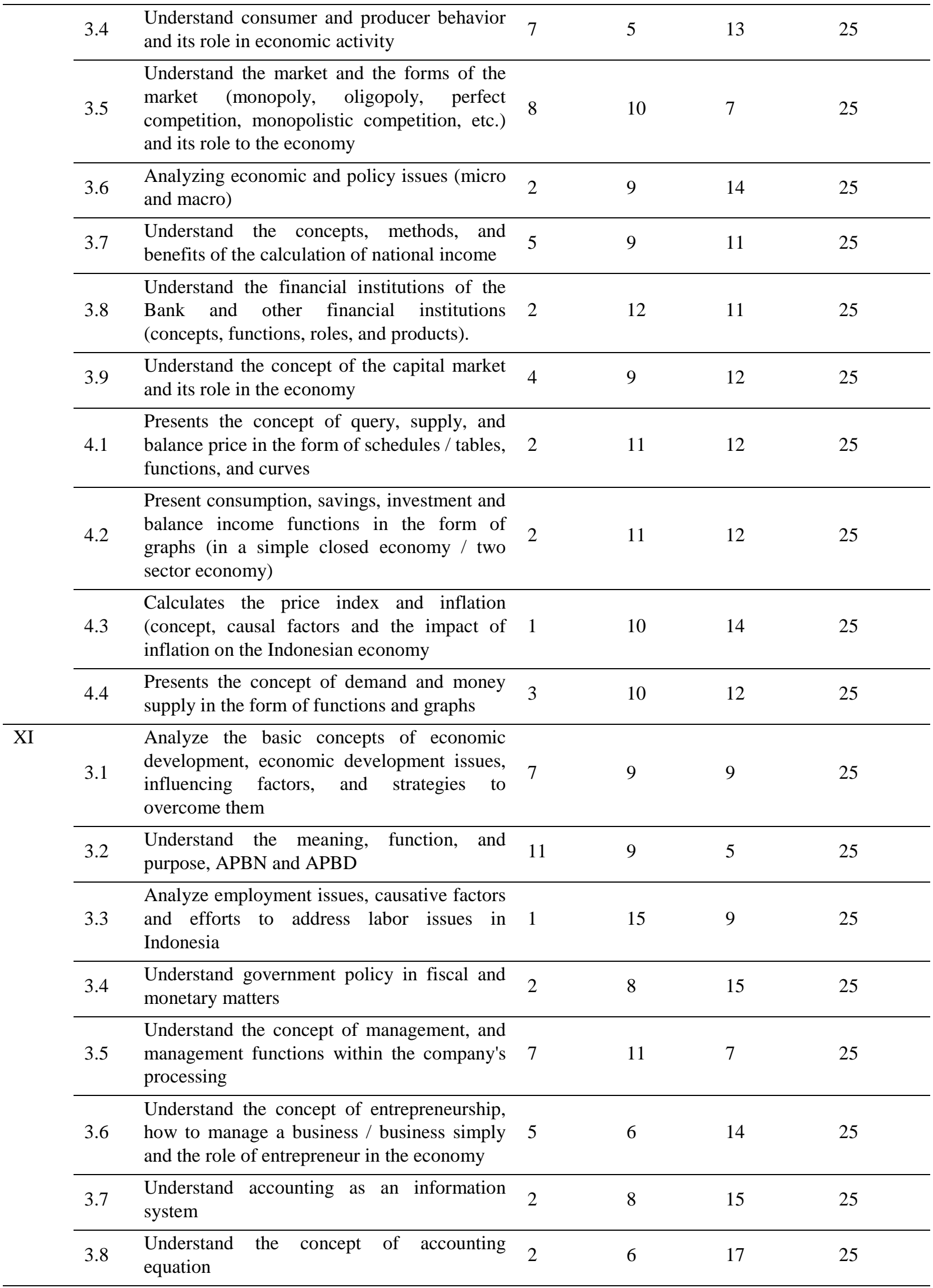




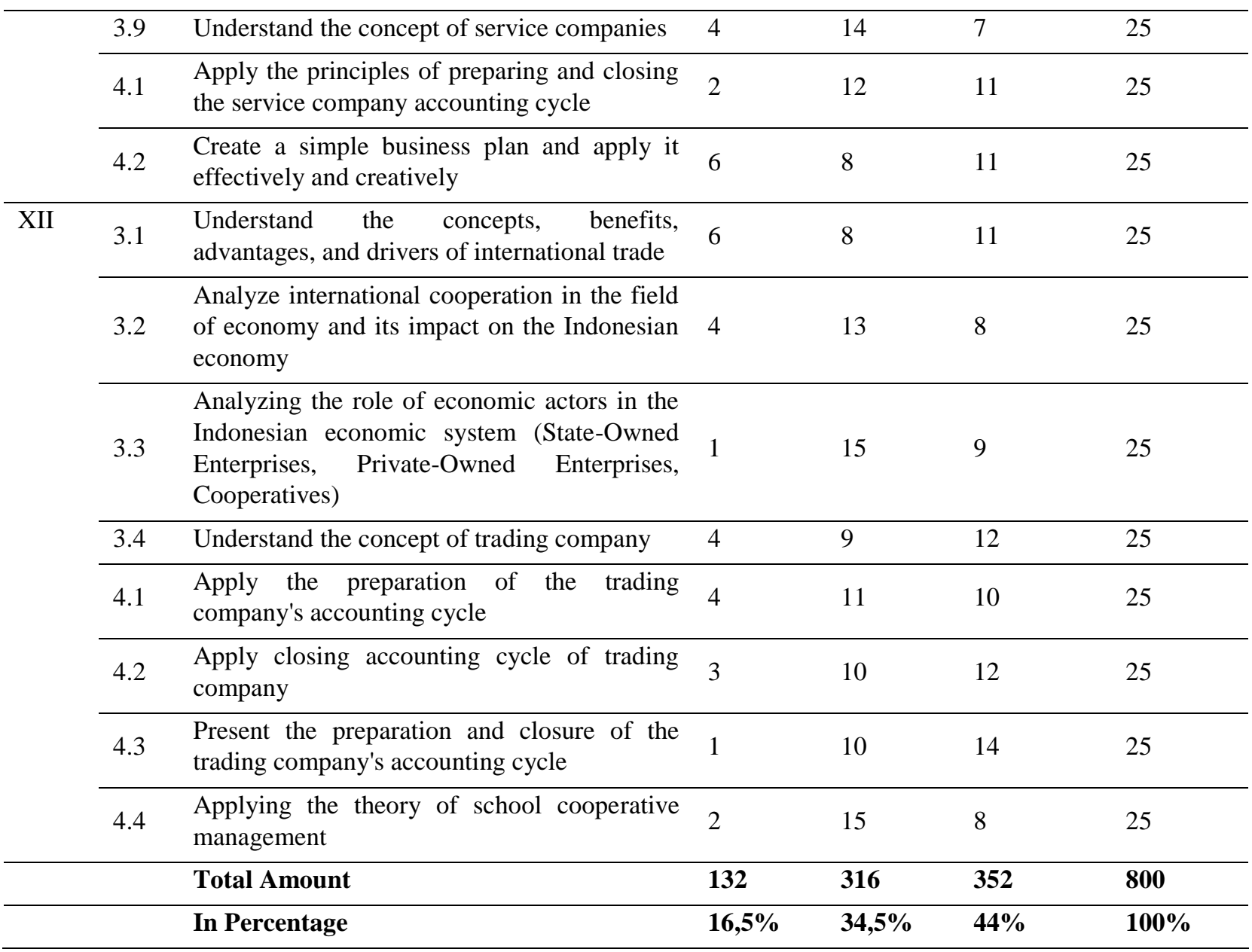

\section{Discussion}

The media used is generally a power point, based on Computer Informatics Technology that has been able to display media in audio, visual, and audio \& visual. The medium is provided by the school through the Deliberation Teachers Subject and some are made by themselves according to the teacher's creativity as well as download appropriate materials from the internet.

The picture of media usage on its competence and suit is $16.5 \%$ using audio, $39.5 \%$ using visual, and audio \& visual media as much as $44 \%$. So it can be seen that the use of more media using audio $\&$ visual.

There are Basic Competencies that can display media based on local wisdom. For example in Basic Competence 3.5 class X on "market" can be displayed the famous traditional market "Floating Market" in Banjarmasin. It's just that the teacher is more tied to a generally accepted textbook. Teachers are less creative than thinking about adding to things related to local wisdom.

Basic Competence Findings and concepts that can be displayed in local wisdom media.

\begin{tabular}{|c|c|c|c|}
\hline \multicolumn{4}{|c|}{ Basic Competencies } \\
\hline No & & About & Material Of Local Wisdom \\
\hline 1 & 3.3 & Analyze employment & $\begin{array}{l}\text { In the Banjar Regency Peatlands during harvest } \\
\text { season, there is labor mobilization, harvesting of } \\
\text { paddy whose salary is divided by proportion in } \\
\text { accordance with the harvest, for example harvesting } \\
10 \text { rice cultivars, paid } 1 \text { tin paddy, either individual } \\
\text { or group. }\end{array}$ \\
\hline
\end{tabular}




\section{Basic Competencies}

\begin{tabular}{|c|c|c|c|}
\hline \multirow[t]{2}{*}{ No } & & About & Material Of Local Wisdom \\
\hline & & & $\begin{array}{l}\text { Mangaruni wetland for example every } 1 \text { piece paddy } \\
\text { can be fixed yield } 1 \text { tin, or in accordance with yield } \\
\text { of harvest. If the } 100 \text { crops harvest is divided into the } \\
\text { proportional tenor of } 10 \text { or } 1: 10\end{array}$ \\
\hline & 3.5 & $\begin{array}{l}\text { Market and its economic } \\
\text { role }\end{array}$ & $\begin{array}{l}\text { Floating Market in Muara Kuin, Lok Baintan in } \\
\text { Banjar District, using Jukung Market and } \\
\text { Tungging Market in Belitung, Banjarmasin kind of } \\
\text { surprised market late evening. }\end{array}$ \\
\hline
\end{tabular}

\begin{tabular}{ll}
\hline 3.63 & Understand the concept \\
& of entrepreneurship, how \\
& to manage a business / \\
& business simply and the \\
& role of entrepreneur in \\
& the economy
\end{tabular}

Particularly at school State Senior High School 4 Banjarmasin, students are taught to entrepreneurship in the form of making their own traditional cloth sasirangan, and they are also marketing it.

There are more business in banjarmasin city, i.e.: collector waiting for the seller, collectors come to the producer, shop sell daily necessities, the traders of many markets are selling for the market, resident trader, boating traders - sailing from city to coastal city, seller allows to vote, deal price selling, and purchase entirely and merged with other items, the Sunday Market, the Monday Market, the Tuesday Market, the Wednesday Market, the Thursday Market, the Friday Market, and the Saturday Market.

\begin{tabular}{lll}
\hline 4 & 4.1 & Supply and demand
\end{tabular}

Local wisdom that is visible is at the time of sale and purchase transactions, there are aggrement sentences spoken at the time of the transaction, the sentence "exchange-selling" sentence "exchange" spoken by the buyer, while the phrase "selling" spoken by the seller.

At the time of the rice harvest season, people who have excess money become "awaiting". He bought directly from farmers, then sold to the market with more price, for example buy 1 tin paddy with the price of 20.000IDR, sold again in the market 1 tin with price of 25.000IDR

\begin{tabular}{lll}
\hline 5.2 & $\begin{array}{l}\text { Consumption, saving, } \\
\text { investment and income: }\end{array}$ & $\begin{array}{l}\text { Teashop in Banjar society this term is defined as } \\
\text { sitting in tea stalls and eat wadai cake as a substitute } \\
\text { for breakfast at home }\end{array}$ \\
& $\begin{array}{l}\text { The habit of Banjar people holding the "mahanyari", } \\
\text { it is a ritual for after each harvest, start a new } \\
\text { business, in order to make business smooth and } \\
\text { blessing. This rituals is for occupy a new home, buy } \\
\text { a new means of transportation to avoid the disaster, }\end{array}$ \\
\hline
\end{tabular}




\section{Basic Competencies}

\begin{tabular}{lll} 
No & About \\
\hline 6 & 4.4 & $\begin{array}{l}\text { The concept of demand } \\
\text { and supply (value for } \\
\text { money) }\end{array}$
\end{tabular}

\section{Material Of Local Wisdom}

Borrowing is associated with gold price. For example; if borrow as much as 10.000.000IDR and if gold price is 500.000IDR per gram, so it is equal to 20 grams of gold, then should be returned with 20 grams of gold also. If the price of gold at the returned time is 600.000IDR per gram, then returned money is. 12.000.000 IDR.

In traditional markets there are sizes:

- Bushels are made of perforated wood, contents $52 \mathrm{~kg}$ of rice.

- $\quad$ Tin is a former kerosene tin, its contents 5 bushels.

- Bamboo basket for the fruit.

- stack of goods volume is area in $10 \times 10$ meters

The local wisdom-based material in economic learning can actually be made a media that shows regional characteristics, with the aim of introducing to students about local wisdom owned by their respective regions, especially in South Kalimantan. Teachers need to be more creative in making media. Now, the teachers themselves do not know much about the activities or terms of trade that are based on local wisdom. The over time did not rule out that later students no longer know about economic activities that show the typical of the region.

\section{Conclusion}

Based on the data obtained and the results of the analysis can be concluded that the use of media in accordance with its competence in learning is as much as $16.5 \%$ using audio, the use of visual media as much as $39.5 \%$, and the use of audio and visual media as much as $44 \%$. There are certain basic competencies that can display local wisdom.

\section{Suggestion}

For the use of instructional media in each school should be used learning media adapted to the basic competence of learning materials and equip it with local wisdom. Teachers individually or discuss it in the Deliberation Teachers Subject to continue to explore the economy based on local wisdom and develop it enriches the students' knowledge.

\section{References}

Anas Sudijono. (2011). Introduction to Education Statistics. Jakarta: Rajawali Pers.

Bretz. (1971). The Selection of Appropriate Communication Media for Instruction: A Guide for Designers of the Airforce Technical Program. California, Santa Monica, Rand.

Kemp \& Dayton (1985). Planning \& Producing Instructional Media. New York, Herper \& Row Publisher.

Keung, C.C. (2009). Cultivating communities of practice via learning study for enhancing teacher learning. KADI journal of educational policy, 6(1), 81-104.

Lai, T.C. (2005). The use of learning study to improve teachers' professional development: A case study. Unpublished M.Ed Dissertation. Hong Kong: Hong University.

Lo, M. L., Pong, W.Y., \& Chik, P.M. (2005). For each and every one: Catering for individual differences through learning studies. Hong Kong: Hong Kong University Press.

Marton, F. and Lo, M L. (2007). Learning from the "Learning Study". The Journal of Teacher Education and Research, 14(1), 31-44.

Marton, F., \& Tsui, A.B.M. (2004). Classroom discourse and the space of learning. Mahwah, NJ: Lawrence Erlbaum Associates, Publishers. 
Ma, L.P. (1999). Knowing and teaching elementary mathematics: Teachers' understanding of fundamental mathematics in China and the United States, Mahwah, NJ: Lawrence Erlbaum Associates.

Miles, M.B \& Huberman, Mihael. (1992). Qualitative Data Analysis. Translator Tjetjep Rohendi Rohidi. Universitas Indonesia Press, Jakarta.

Pang, M.F. (2002). Making learning possible: The use of variations in the learning school economics. Unpublished PhD Thesis, Hong Kong: University of Hong Kong.

Pang, M. F. (2006). The Use of Learning Study to enhance teacher professional learning in Hong Kong. Teaching Education, 17(1), 27-42. https://doi.org/10.1080/10476210500527915

Runesson, U. (2005). Beyond discourse and interaction. Variation: a critical aspect for teaching and learning mathematics. The Cambridge Journal of Education, 35(1), 69-87. https://doi.org/10.1080/0305764042000332506

Shramm, W. (1977). Big Media Little Media. London, Sage Publications.

Thabit, A.M. (2006). Teachers "awareness of dimensions of variation: A mathematics intervention project. In Hewitt, D. (2006). Proceedings of the British Society for Research into Learning Mathematics, 26(1), Department of Educational Studies, University of Oxford. 